\title{
CONCEPTUAL BASIS FOR UKRAINIAN RURAL DEVELOPMENT
}

\author{
Maria Plotnikova ${ }^{1}$ \\ Zhytomyr National Agroecological University (Ukraine)
}

\begin{abstract}
The presence of imbalances and asymmetries of the rural development form the need of harmonious development directions of the village that led to the choice of a researched topic. The aim of this work is to find and study areas and mechanisms for the orderly development of rural areas based on the principles of formation food and economic security, organic farming, and waste-free life and bio-adequate approaches in growing up and education. The study covers the period from 1991 to 2014. Evaluation of the results was based on sociometric and statistical methods. Theoretical and methodological basis of research was grounded on system-synergetic approach to the study and modelling of socio-economic processes. It was formed a model of dynamic ecological social and economic settlement system capable of self-sufficiency. Specificity of the organization and functioning of the environmental settlements in terms of global challenges was identified.

KEY WORDS: investments, innovations, management, development of rural territories.
\end{abstract}

JEL CODES: D 83, O 10, R 28, Q 01, Q 18.

\section{Introduction}

Understanding of the need for improving of the level and quality of life, forming the foundations of food and economic security at the global, supranational, national, regional and local levels identified a vector of rural development and research of foreign and domestic scientists. Currently, this indicator is dealing with finding of a modern man with healthy lifestyle, finding mechanisms for restoration ecology, development of new technologies, formation of social society based on raising awareness and providing direct democracy through local communities.

Business technology that transformed the product highlighting mostly standardized external characteristics deprived a product inherent to it individuality and consumer-healing component. As a result of such business technologies there has been changes in the environment, human health deterioration, which led a last one to become a hostage of the system. It is known that the formation of any structure comes from the material of which it is built and it is the basis of the produced object (such as "we are what we eat"). In contrast to the technocratic-globalization processes of the world economy in almost all countries there were ecological settlement as an alternative model of the future society that lives in harmony with nature. Residents of these settlements grow food from seeds of mainly local varieties breeding. Such foods are juicy, fragrant with the characteristic features of species, they are pleasant to eat. Unlike modern technology oriented on the intensive approaches to production and where the main focus is a large-scale production, ease of packaging

Maria Plotnikova - assistant of professor, PhD, Zhytomyr National Agroecological University, Ukraine. Scientific interests: systematic development of the settlements network in rural areas

E-mail: marianma@yandex.ru.

Tel. + 380674400349 
methods, transport and storage, traditional ones preserve the natural integrity of the product and its consumer component. Conceptual intention of the synergistic, symbiotic and other forms of configurative cooperation with nature get to eco-friendly products and nutritious, healthful and delicious food, characterized by growing demand from the population.

The problems of intensifying and harmonizing of socio-economic relations, organizations, investment and innovation activities to rural development work are the subject of numerous domestic and foreign researchers. These are the results of studies of N. Zinovchuk, V. Zynovchuka, O. Skydan (Органічне, 2011). Aspects of regional areas development, the possibility of using European and world experience of national and supranational formations described by T. Zinchuk, Y. Hubeni (Зінчук, 2008; Губені, 2005). Theoretical, methodological and practical aspects of rural development and prospects of optimization of national agricultural policies are the focus of the works of Smith, 1987; Christian, 2003; Gilman, 2013; Inspring, 2013; Living, 2013; Теорія, 2010; Українська, 2012; Збарський, 2010; Прокопа, 2005; Українське, 1991; Юрчишин, 2011. The issue of resource supply due to limitations of their amount and their involvement in the production process is the subject of the research by L. Davydenko (Давыденко, 2014). Directions for problem solving of the depressed areas are reflected in a number of legal acts adopted at a higher level in the country (Генеральна, 2002; Державна, 2007; Державна, 2011). However, the presence of asymmetries and imbalances in agricultural development require further economic, political, environmental and social changes in the global economic system and in Ukraine in particular. Growing needs of producers and users of natural resources require members of the public relations opportunities to ensure sustainable development for both the global and regional levels, which in turn will increase the production rate of economic growth, as well as harmonization of the relationship between man and nature. The subsequent emergence of new promising areas of rural development and opportunities for their popularization identified direction of the research.

The aim of the study is to find and ground a mechanisms of providing a multi-functional rural development in conditions of global challenges and decentralization of public administration in Ukraine. The objectives are to study the essence of the notion of rural development, analysis of the current state of rural development and design of processes to stimulate environmental and socio-economic development of rural population. The object of the research is the socio-economic and environmental approaches to enhance the capacity of rural areas. The subject of the research is theoretical and methodological principles that reveal the essence of socio-demographic situation in rural areas. The study covers the period from 1991 to 2014 analyzed and classified on the basis of sociometric research and statistical surveys. The theoretical basis of the study is the formalized theory of economic systems, which reflects a systematic approach. Theoretical and methodological foundations have been formed based on works by domestic and foreign scholars in the field of rural development, legal acts and sector's standards (analysis of current approaches, methods and technologies for territories management, assessment of their effectiveness); system analysis and general systems theory (formation of conceptual approaches for Regional Development) system analysis and general system theories (defined conditions of a stable development of the rural areas made a forecast of optimization of administrative influence on the agricultural sector at the macro-, meso- and micro- levels).

\section{Rural Development System and Theoretical Aspects of the Issues}

The global and domestic practice of the economic activity and population showed that the effect of technological choice of humanity became available social and environmental situation in the world, within countries and regions. In particular, the US experience of the eighteenth century. Ukraine and at the end of the twentieth demonstrated stability of small forms that operate in rural areas before the outside interference and a higher potential of the natural form of management compared to a goods one from the standpoint of life quality assurance, food security and greening habitat (Christian, 2003; GEN; Плотнікова Багатофункціональний, 2014; Плотнікова Соціально, 2015; Плотнікова Соціально, 2014). Thus, even lobbying for their own interests by the large farms on the legislative, administrative and other levels do not 
allow to change the situation recognized by the official statistics - a dominant share of national output of grown fruits, vegetables, berries, potatoes, milk and meat cattle, pigs, etc. is in households compared to the public sector of the economy (Державна служба, 2015). The private sector is an important source of income, forming the basis of demographics, resources for employment, foundation food and economic security (Smith, 1987; Plotnikova, Innovational, 2014; Plotnikova, Innovative, 2014).

The practice of moving to rural areas is good for demographic situation and supports the revival of areas. According to statistical surveys a higher birth rate and better health, higher life expectancy among parents of reproductive age, lower divorce rate, diseases of the population of working age belong to the rural areas not the urban ones (Living, 2013; Inspiring, 2013; Плотнікова Еволюційно, 2014; Плотнікова Перспективи, 2014). Thus, the intensity of the burden on urban residents are not fully compensated with receiving of higher levels of income. City dwellers into the rural areas become to be organic crops growers, use technologies of non-waste principles, include alternative energy sources, use fast restored resources and nature according methods of education and training (noosphere education). A revival of national customs and traditions is made on a new basis. The main at this approach belongs to a new level of consciousness and human responsibility for the environment and own conscious gradual progressive movement forward. Qualitative changes in the structure of society and its individual elements can change their status and to respond constructively to solve problems identified. Structural mechanism of formation of a personality on the example is shown in Fig. 1.

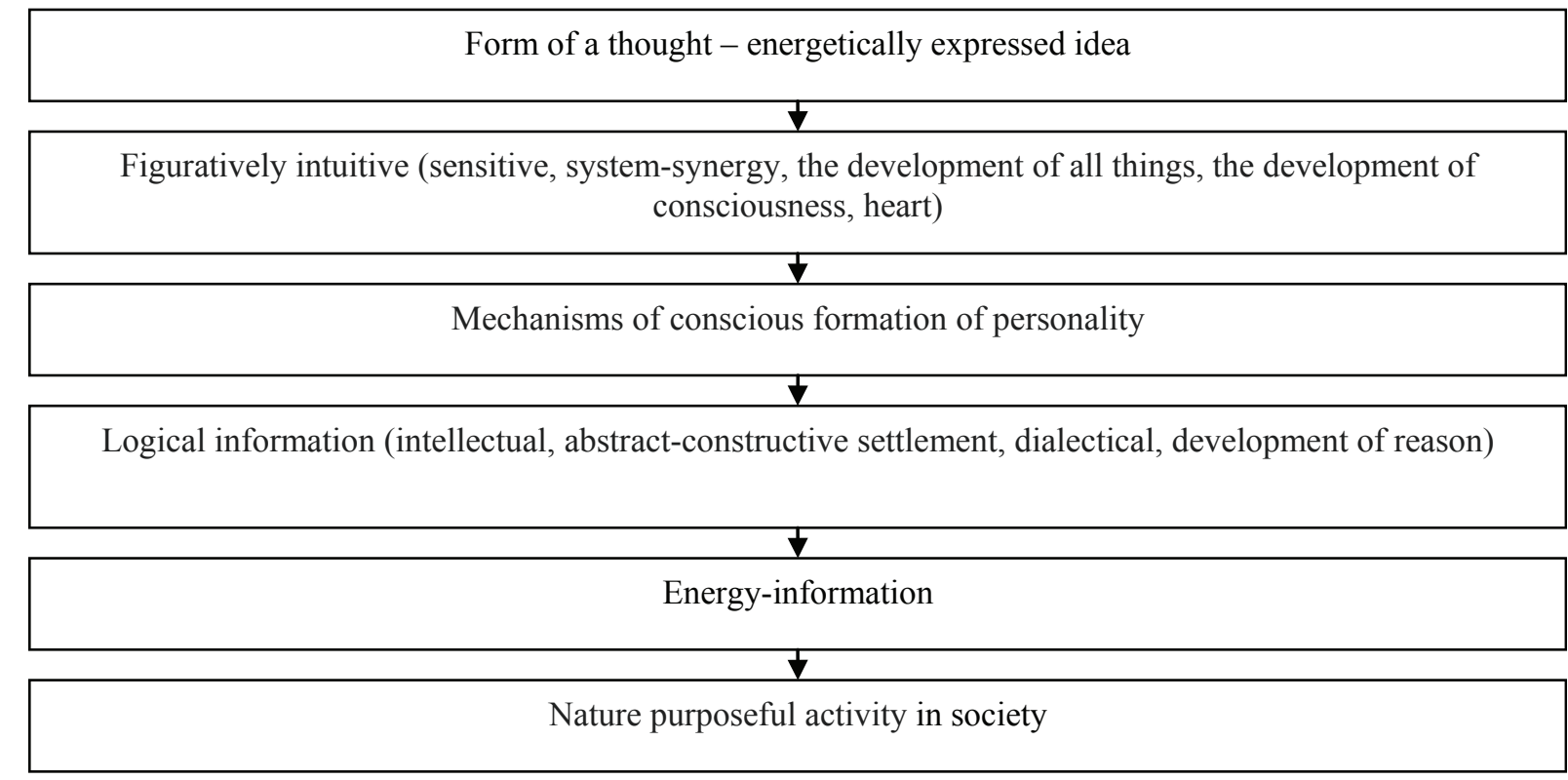

Fig. 1. Mechanisms of conscious formation of the individual, society

Source: own research

Development of figurative-intuitive perception is built on the identification of visual features of the object or image that later processed information from a number of positions, forming the equivalent analog data bank. From this perspective, development is a progressive movement forward, conscious transformation of the pillars forming the natural energy balance through a permanent, high-quality refill for maximum filling volumes and climbing the social structure. It should be noted that the varied manifestations of the universe, each of them has a motion vector toward a common goal, which is defined as the trajectory, speed, time, willingness consciousness starting potential and mechanism of movement.

According to research by M. Porter, competitiveness of market conditions is characterized with their better ability to demonstrate higher performance indicators compared to the main competitors within a certain period of time, which is possible including monopoly of the entity in the absence of competition. Taken the above into consideration, support of a national identity is able to form a niche where there is a national com- 
petitiveness in conditions of global challenges. While the general trend towards urbanization, technocratic way and globalization processes in general create conditions for the unification of national interests and identity as improving processes, subjects of management, and the goods offered by them. Alternative trends emerged in the world over the past fifty years are one containing the desire to abandon the competition. The well-known agrarian revolutionary the Austrian farmer Sepp Holzer refuses to compete with his neighbours creating new niches for economic activities, offering new products and methods of presentation to the consumer, refusing from patenting his experience in order to share with all willing (Хольцер, 2009). In Ukraine, a similar movement is on the organization and arrangement of tribal estates and tribal settlements. The main idea of which is arrangement on the site for at least 1 hectare by each willing adult citizen of Ukraine or a family of an independent self-efficient eco-friendly environment where it is possible to lead a harmonious life. The practice of economic activity and social processes in rural areas of Ukraine shows that at this site, which lovingly fitted for 10 years without sufficient labor, material and financial costs can produce more than 20 tons of wonderful organic foods. This activity is not farming. Special is the relationship of man with the land - area is not a subject to alienation, sale or mortgage, it can only be transferred and inherited. This brings economic benefits of naturally grounded management and life. A comparative analysis of Eastern and Western management practices in rural areas showed positive effects of systematic approach and tribal way as from both a position of forming of the spiritual component of public relations, and economic feasibility of cooperation efforts at all levels. Taken into consideration the trends of modern society its future is formed in issues of its life in the area. Taken into consideration the trends of Ukrainian European development, the future of society is based on the activities of local communities (religious adherents), and the fundamentals of the production of wealth - are realized through the mechanisms provided for in the consumer associations (communities, participation in whose management and activities is implemented on the basis of equity contributions). There is a corresponding legislative reinforcement. The society of the future is built on the principles of organic farming, waste-free life, use of renewable energy sources and bio-adequate approaches in education and upbringing of children, providing permanent spiritual improvement of each individual who lives in the village. It has to be noted that cooperation with nature, observation and careful attitude, particularly from the side of system-synergetic approach, is forming the foundations for sustainable growth, and creating conditions for improving the people's quality of life forming the foundations of food, economic and environmental security and development in the long run.

In order to implement the tasks of multifunctional agriculture development in Ukraine in the long run by the central and local authorities, scientific and educational institutions and public organizations and initiative groups are working on collaboration, decentralization of power and increasing of self-sufficiency in rural areas (Fig. 2). Transfer of the land into the life use without a right to sell and having a right to transfer it only as a legacy creates conditions for a more responsible and less consumer relationship to the land and the environment compared to the terms of the lease.

Human history has repeatedly argued that the basis of the development is the spiritual awareness by the human being of his role in the world and the growth of consciousness. The combined effect on the nature of purposeful human activity is reflected in the works of S. Podolynskiy, V. Vernadskiy, N. Rudenko, who noted the necessity of forming conscious attitude to the surrounding world, intellectualization of society, creating conditions for strengthening and expanding human potential and capital, and can reach and effect of synergy image-intuitive and logical first intellectually approaches in the rural development management in the country. Practical realization character of mankind heritage as a form of expression of open society is a guarantee of the preservation of its degradation. Further development of the acquired knowledge and dissemination of the principles of cooperation increases the stability of the system as a self-organized structure.

\section{Character and prospects of rural territories development of Ukraine}

The practice of economic and socio-economic activities of agricultural holdings in Ukraine, the land bank of which in 2012 amounted 3,000,000 ha, and total revenues - 93 billion USD. (Агробізнес, 2013), 
showed a relatively low level of interest in social and environmental areas development where economic activity is conducted. At the same time consumers and enterprises workers are crucial component of their success. Increasing awareness of the people mentioned towards the ecological trendiness of the production dictates the choice of the vector of all entities in rural areas.

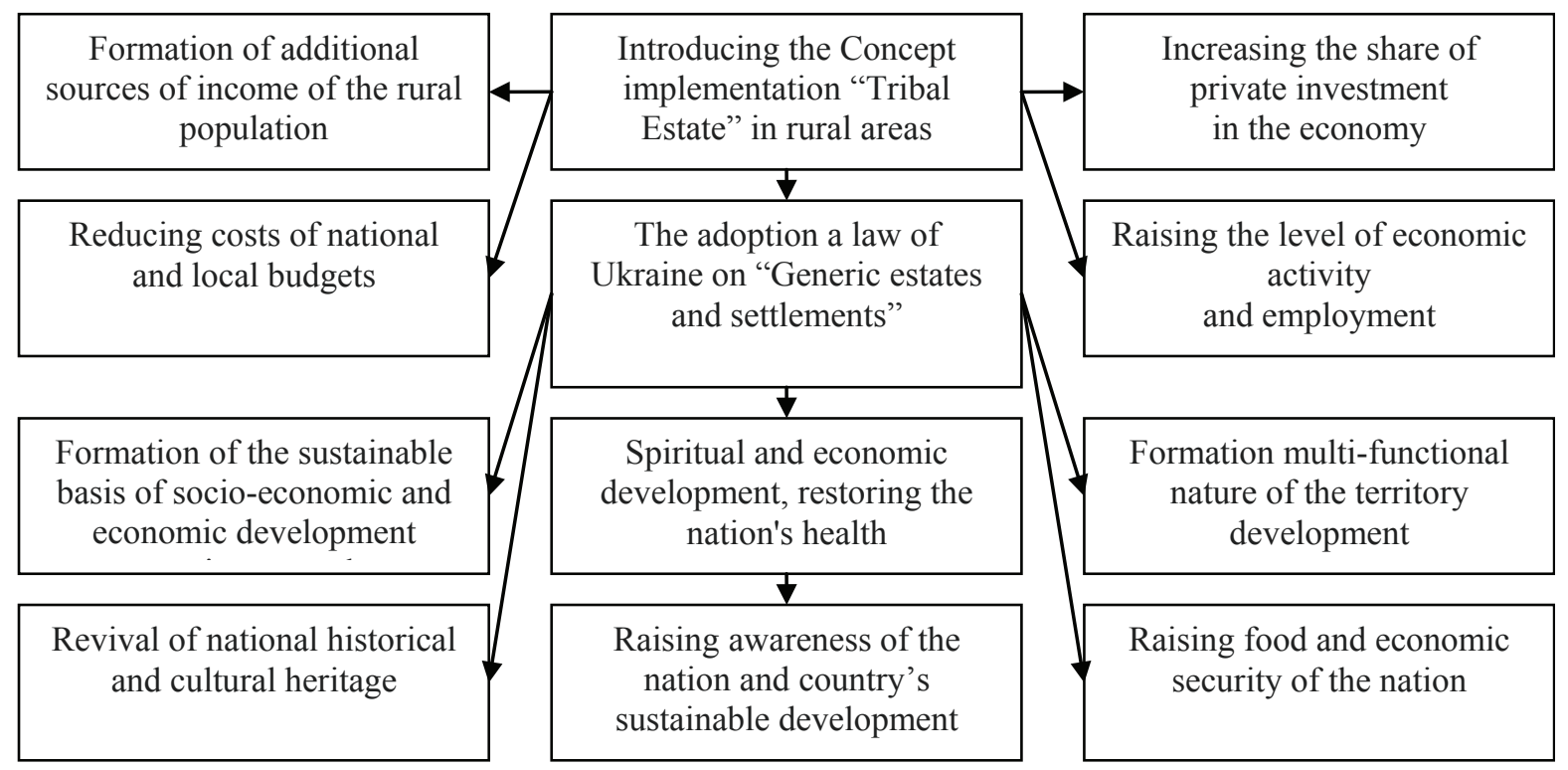

Fig. 2. The results of the implementation of the idea of "Tribal Estate"

Source: own research.

The analysis of regional development of Ukraine outlined the leading positions of Western and Central regions of the country from the point of evaluation of their production and resource potential and prospects for activity. Zoning regions of Ukraine due to the specialization, geographical location and level of economic development for the Central West, North East and South let us evaluate three separate trends. Seasonal nature of the Southern region and relatively lower pace of development indicate a relatively higher amplitude fluctuations in production and sales, with a peak in June. A sustainable development of the North Eastern region is caused by the predominance of livestock industries and suburban character of zone economy. Much accelerated pace in production in Western and Central regions, with a peak in July accompanied with the increasing of the production pace. The latter is associated with both higher levels of use of existing resources and increasing pressure on the environment (Table 1). While in the Western and Central regions the main pollutant is transport, in the North-Eastern region it is industry. Features of zonal vegetation foster forestation of the Central and Western regions, the restoration of forests and higher volume of wood production. However, it is noted below the lower level of afforestation of all the areas of the country.

Production of the major livestock products is characterized by a national trend (with a slight increase in the number of pigs, other categories of animals and poultry tend to reduce their stock). Zoning features of the distribution of livestock production sector are associated mainly with soil -climate conditions. In particular, the prevailing position of the Central and Western regions are supported in addition to the natural factors with also availability of the markets for the products, which forms a stable market position in the region from year to year. Similar trends are accompanying crop production. However, the best climate for growing of the sunflowers has defined its production in the North-Eastern region, while the seasonal production of open ground vegetables is concentrated in the South. High demand for products and relatively low production generates higher, compared to the other regions, level of agricultural prices in the North-Eastern region. Employment in all sectors and in agriculture, forestry and fisheries, in particular, is consistently higher in the Central and Western regions, due to including higher economic activity of business entities. 


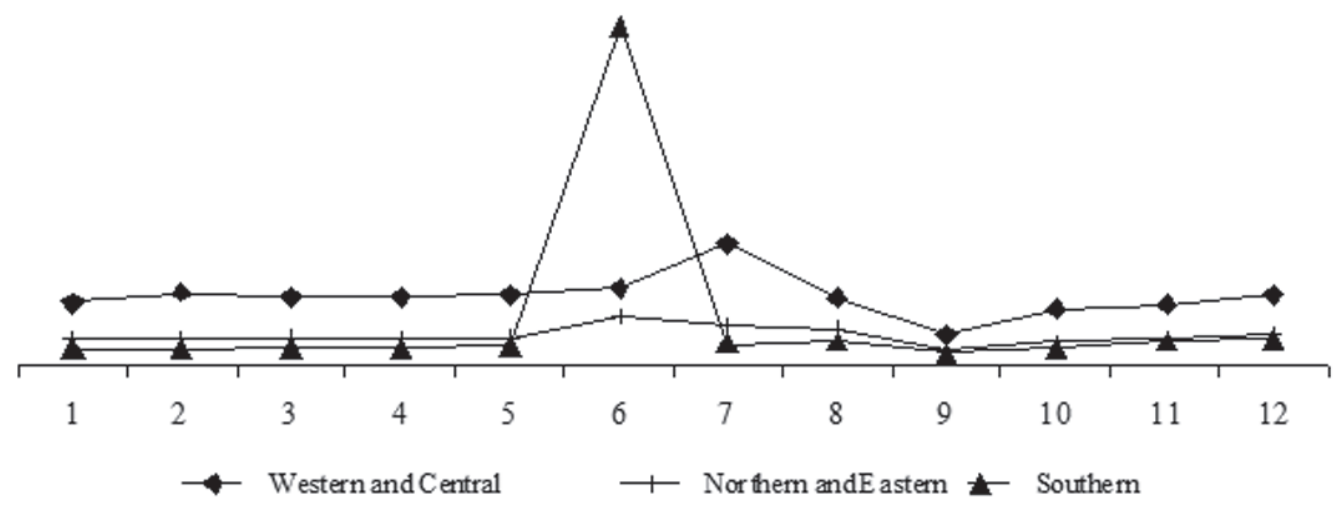

Fig. 3. Index ezonn spine with agricultural production regions of Ukraine for the month of the year on average in 2012-2014

Source: formed on the basis (Державна, 2015).

Experience of managing in the US within late eighteenth century and Ukraine in the late twentieth early twenty first century illustrated higher stability in dealing with social and economic crisis at the side of a natural form of management compared to the merchandise (Соединенные 1960, Державна, 2015). In particular, even lobbying their interests in legislative, administrative and other levels of government and management do not allow big companies to avoid bankruptcy, while private farms and households having no support remain active participants in public relations and significant producers (the proportion of products grown by them livestock, vegetables, fruits, potatoes and other products is $60-70 \%$ and in some commodity groups $80-90 \%$ of the national figure). In addition, this sector remains the main supplier of labour, a source of revenue for the budgets of all levels and guarantee of food and economic security, and hence the independence of the state.

Trends for the demise of rural areas (for 1990-2013 their number decreased by 454 units, or 17 per year - Кропивко, 2015) followed by appearances and growth of new settlements in rural areas by settlers from the cities. As this issue study by the workers of the Ministry Agrarian Policy and Food of Ukraine and the National Academy of Agricultural Sciences (National Scientific Centre "Institute of the Agricultural Economics") held on behalf of the board of Ministry with a direct going to the site of the existing and new type of settlement (plots of 1 hectare), showed their development belongs to the change of consciousness (Стратегічний, 2012).

In making the decision to change priorities in life, material factors act as secondary (technical), giving priority of clean air, clean water, clean food, organizing life in harmony with nature, health, children and friends. Thus this change of priorities in the organization of new settlements in rural areas, as opposed to generally accepted approaches, raises of course a different interpretation of such settlements in rural areas. In conventional approaches to the analysis of the situation in rural areas such figures and trends appear: low level of employment, wages, gasification, road surface, water and district heating; reducing network of schools and pre-schools, kindergartens, village health centres; absence or irregular nature of bus service; wide range of other social problems, forcing villagers to travel to cities or abroad. Life pace of environmental and tribal settlements with the lowest values to the characteristics mentioned above, from scratch, illustrates an example of a district with a high quality of life. Forming or reviving settlements in rural areas, the settlers are building housing, roads, schools, houses of culture and creativity, healing, health and recreational facilities.

The average age of the settlers is thirty-five years which enhances fertility, "the rejuvenation of the village", the return of national customs and traditions, folk crafts, etc. So we see two processes in the development of society: 
1. Capitalistic (market) - key point for its development are - the rate of profit (Karl Marx). This process of social development, as industrialization (urbanization) - technocratic approaches in manufacturing, consumer approaches to life, - went to "dead end" of a social development that was noted in UN documents. Whereas Ukraine has been on the path of market relations only since 1991, the process of urbanization (savage capitalism) in our country is in full swing and people replenish cities, of course, at the expense of rural residents.

Table 1. Key development indicators in the region along with Ukraine

\begin{tabular}{|c|c|c|c|c|}
\hline Indicator & $\begin{array}{l}\text { Western } \\
\text { and Central } \\
\text { regions }\end{array}$ & $\begin{array}{l}\text { North-East } \\
\text { region }\end{array}$ & $\begin{array}{l}\text { Southern } \\
\text { Region }\end{array}$ & $\begin{array}{l}\text { Ukraine } \\
- \text { all }\end{array}$ \\
\hline The volume of emissions (2014), th. tons & $1,779.6$ & $1,723.5$ & $1,683.5$ & $5,186.6$ \\
\hline Besides emissions of dioxin (2014), th. tons & 56582.6 & 64129.0 & 60220.9 & 180932.5 \\
\hline $\begin{array}{l}\text { The volume of products, works and services of forest } \\
\text { households (at current prices in 2014) mln. USD }\end{array}$ & $6,548.1$ & 885.5 & 306.3 & $7,739.9$ \\
\hline Restoration of the forest (2014), th. ha & 46.3 & 7.8 & 3.9 & 58.0 \\
\hline $\begin{array}{l}\text { The costs of protection and rational use of natural resources } \\
\text { (2014) th. UAH }\end{array}$ & 8061792 & 3939778 & 10147168 & 21925579 \\
\hline \multicolumn{5}{|l|}{ Livestock and poultry (on average in $2012-2014$.) $\mathrm{mln}$. pcs. } \\
\hline Cattle & 2.03 & 0.91 & 1.44 & 4.38 \\
\hline including cows & 1.22 & 0.49 & 0.77 & 2.48 \\
\hline pigs & 4.00 & 1.24 & 2.32 & 7,56 \\
\hline sheep and goats & 1.16 & 0.24 & 0.25 & 1.65 \\
\hline poultry & 113.82 & 33.10 & 64.82 & 211.74 \\
\hline \multicolumn{5}{|l|}{$\begin{array}{l}\text { Production of major livestock production (average in 2012- } \\
2014 \text { ) }\end{array}$} \\
\hline milk, th. tons & $1,993.68$ & 499.95 & 736.05 & $3,229.68$ \\
\hline Meat (live weight), th. tons & $6,691.5$ & $2,268.8$ & $2,135.9$ & 11096.2 \\
\hline eggs, mln. pcs. & 10117.3 & $4,309.9$ & $4,731.5$ & 19158.7 \\
\hline \multicolumn{5}{|l|}{$\begin{array}{l}\text { Production of major products of plant production (on average } \\
\text { in 2012-2014.), th. tons }\end{array}$} \\
\hline grain and leguminous crops (without the cleaning) & $20,203.75$ & $11,430.08$ & $12,077.13$ & $43,710.96$ \\
\hline sugar beet (factory) & $10,853.07$ & $2,763.19$ & 574.49 & $14,190.75$ \\
\hline sunflower seeds (without the cleaning) & $1,690.91$ & $3,231.10$ & $4,370.93$ & $9,292.94$ \\
\hline potato & $12,171.10$ & $3,288.50$ & $1,963.65$ & $17,423.25$ \\
\hline open ground vegetables & $3,008.70$ & $1,624.38$ & $2,912.15$ & $7,545.23$ \\
\hline \multicolumn{5}{|l|}{$\begin{array}{l}\text { Average selling prices of agricultural products } 1 \text { by region, } \\
\text { UAH per ton }\end{array}$} \\
\hline grains and legumes & $1,865.2$ & $3,794.1$ & $1,880.4$ & $1,920.0$ \\
\hline cattle and poultry (live weight) & 15894.5 & 31305.9 & 15276.9 & 15689.1 \\
\hline milk and milk products & $3,457.0$ & $6,896.6$ & $3,383.3$ & $3,465.0$ \\
\hline eggs per th. pcs. & 740.8 & $1,519.6$ & 750.0 & 812.5 \\
\hline Employment in Ukraine (on average in 2012-2014.) - total, th. & $8,838.6$ & $5,271.1$ & $5,381.7$ & 19491.4 \\
\hline including agriculture, forestry and fisheries & $1,717.6$ & 738.9 & 928.6 & $3,385.1$ \\
\hline $\begin{array}{l}\text { The total number of active enterprises in Ukraine (on average } \\
\text { in 2012-2014.), in th. }\end{array}$ & 325968.3 & 138541.7 & 86751.0 & 551261.0 \\
\hline including agriculture, forestry and fisheries & 18673.0 & $9,053.5$ & $9,811.0$ & 37537.5 \\
\hline
\end{tabular}

Source: formed on the basis (State, 2015).

2. Social and environmental (family farms, tribal and environmental settlements) - determinant of development sees the principle of necessary sufficiency of material goods, providing the possibility of permanent spiritual improvement. 
Life in nature creates a new level of consciousness that promotes healthier nation, revival of historical and cultural heritage, handicrafts, creates conditions for attraction of its own private investment, increases employment, including through diversification (shift from agricultural production to refining, industrial production, incl. furniture, woodworking, sewing, etc., the provision of services, incl. green tourism, repair, consulting and advisory activity, infrastructure); developments in education (incl. noosphere); reducing the burden on the environment, objects of industrial and social infrastructure in the cities; improvement of agricultural raw materials in place of their production.

Ternopilska
Zakarpatska
Volynska
Ivano-Frankivska
Cherkaska
Chernivetska
Donetska
Khmelnytska
Rivnenska
Vinnytska
Zaporizka
Dnipropetrovska
Odeska
AR Krym
Luhanska
Khersonska
Lvivska
Mykolayivska
Kirovogradska
Sumska
Chernihivska
Zhytomyrska
Poltavska
Kharkivska
Kyivska

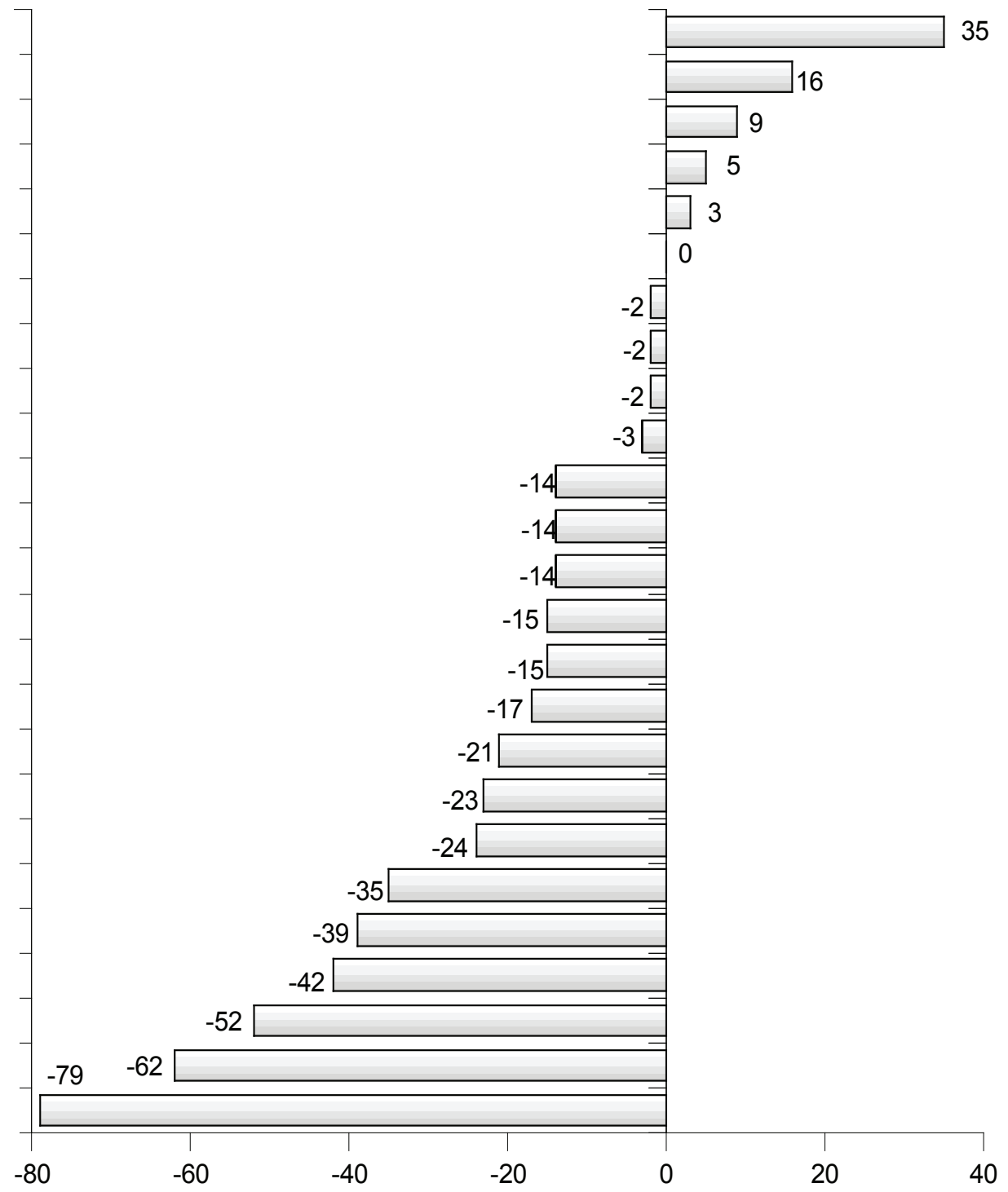

Fig. 4. The dynamics of rural villages and settlements in Ukraine in 1991-2013

Source: formed according to (Кропивко, 2015).

Handling and processing of local raw materials, environmental technologies, particularly in construction contribute to the work motivation and self-motivation itself of the settlers which is socially and environmentally appropriate, and contribute to the restoration of the resource potential of the territory, promote an active role of local communities which are targeted sector of the national program of decentralization of power. Therefore, standard approaches, which are used in the analysis of socio-economic processes in 
rural areas in the market, in the case of the revival of the village by organizing tribal settlements, are not triggered. Moreover, in practice, tribal settlements appear, paradoxically, in the rural areas with the worst indicators of socio-economic development. To some extent, the fate of these villages can be compared to a man who survived clinical death. Typically, after clinical death a man takes such physical and spiritual properties, which he (a man) has not had before. Villages where left several people, or ones being somewhere administrative and territorial centers having simultaneously no residences on its territory, with the advent of the settlers begin to renovate on a new moral - psychological basis not only through these, new residents, but also by coming home of those who hails from the village and decided to go back after seeing its revival. These villages are filled with new young people with new visions of life and a new outlook on these areas and new approaches to life and life of a separate tribal estates and settlement (settlement) in general.

\section{Conclusion}

Thus, the rural development can be considered as progressive systemic conscious purposeful movement forward, accompanied by the growth of natural energy balance of rural areas through its continuous increasing volumes of resource potential and hierarchical increase of individual territories as a whole system.

There are low employment, wages, gasification, road surface, water and district heating; reduction of network of schools and pre-schools, kindergartens, village health centres; absence or irregular nature of bus service as a result of imperfect agrarian policy in Ukraine. These widely ranged social problems were forcing villagers to live in cities or abroad. But the trends for the demise of rural areas are accompanied by appearances and growth of new settlements in rural areas by settlers from the cities. These activities show the changes of consciousness. Reviving settlements in rural areas, the settlers are building housing, roads, schools, houses of culture and creativity, healing, health and recreational facilities. The average age of the settlers is thirty-five years. It is good for enhancement of development, fertility, the return of national customs and traditions, folk crafts, etc.

The strategic importance for the development of rural areas, forming the foundation for the nation's self-determination, food and economic security governance is adoption of the law on free rights for any Ukrainian family to get 1 hectare of land for making patrimony. This land can be taken free, without right of sale or pledge but only with the right to transfer it inherited. Public-private partnerships in work of organizing the planned development of the network of settlements in rural areas will increase revenues to local and national budgets and solve socio-economic problems of these territories.

\section{References}

Christian, D. L. (2003). Creating a Life Together: Practical Tools to Grow Ecovillages and Intentional Communities. Paperback: New Society Publishers, 273 p. Internet access: https://archive.org/details/fa_Creating_a_Life_TogetherPractical_Tools_to_Grow_Ecovillages_and_Intentio nal_com

GEN (Global Ecovilladg Network). Internet access: http://gen.ecovillage.org

Gilman, R. (2013). The Eco-village Challenge. The challenge of developing a community living in balanced harmony - with itself as well as nature - is tough, but attainable. Context Institute. Catalyzing a graceful transition to the Planetary Era. Internet access: http://www.context. org/iclib/ic29/gilman1/

Living in harmony: inspring stories from ecovillages. (2013). Ed. D. Vidickiene. Vilnius: BMK, 124 p.

Inspring Stories from Ecovillages: Experiences with Ecological Technologies and Practices. (2013). Eds. A. Palojarvi, J. Pyysiainen, M. Saloranta. Vilnius: BMK, 120 p.

Plotnikova, M. Bogoyavlenska Y. (2014). Innovational investment development vector of rural territories. Management Theory and Studies for Rural Business and Infrastructure Development, Vol. 36, №2, p. 382-393.

Plotnikova, M. (2014). Innovative character of rural territories social potential realization. Management Theory and Studies for Rural Business and Infrastructure Development, Vol.36. №4, p. 956-958. 
Smith, J. R. (1987). Tree Crops: A Permanent Agriculture. Island Press, 32 p.

Агробізнес України. (2013). Інфорграфічний довідник. Щорічне видання. Internet access: http://agrex.gov.ua/wpcontent/uploads/Infografika-silskogo-gospodarstva-Ukrayini-vid-BakerTilly-ta-Latifundist.pdf

Давыденко, Л. Н. (2014). Институционализаиия рынка природных. Минск: ИВЦ Минфина, 256 с.

Державна служба статистики України. Офіційний сайт. Internet access: http://www.ukrstat.gov.ua/

Державна цільова програма розвитку українського села на період до 2015 року. (2007). Постанова Кабінету Міністрів України від 19 вересня 2007 р. № 1158. Офіційний вісник Украӥни, № 73 , с. 7.

Державна цільова програма розвитку украӥнського села на період до 2015 року. Із змінами, внесеними згідно 3 Постановою КМ № 1390 (1390-2011-п) від 28.12.2011. http://zakon2.rada.gov.ua/laws/show/1158-2007$\% \mathrm{D} 0 \% \mathrm{BF}$

Генеральна схема планування території України. (2002). Закон України від 07.02.2002 №3059-ІІІ із змінами, внесеними згідно із Законом №5459-VI від 16.10.2012 // ВBР, № 30, с. 204.

Губені, Ю. Е. (2005). Трансформація аграрних відносин у Чехії: загальний огляд та можливі уроки для вітчизняної аграрної політики. Економіка України, № 6, с. 79-83.

Збарський, В. К. (2010) Сталий розвиток сільських територій: проблеми і перспективи. Економіка АПК, № 11, c. $129-136$.

Зінчук, Т. О. (2008). Свропейська інтеграиія: проблеми адаптації аграрного сектора економіки. Житомир: ДВН3 «Державний агроекологічний університет», с. 193-194.

Кропивко, М. М. (2015). Організаційні особливості створення родових садиб як альтернативної форми розвитку господарств населення. Збірник наукових праиь Науковий вісник Мукачівського державного університету. Серія «Економіка»: Т. В. Черниченко (гол. ред.). Мукачево: Вид-во «Карпатська вежа», випуск 5(4), ч. 2, с. 24-29.

Органічне сільське господарство та його розвиток в умовах кооперачії. (2011). Ред.: Н. В. Зіновчук, В. В. Зіновчук, О. В. Скидан (ред.). Житомир: «Рута», 160 с.

Плотнікова, М. Ф. (2014). Багатофункціональний підхід в управлінні сільським розвитком в умовах глобалізації. Продуктивність агропромислового виробнищтва (економічні науки), № 26, с. 140-151.

Плотнікова, М. Ф. (2015). Соціально-екологічні аспекти розвитку агробізнесу. Формування ринкової економіки, № 33, с. 310-321.

Плотнікова, М. Ф. (2014). Соціально-економічні основи створення екопоселень як моделі розвитку суспільства. Збірник наукових праць Таврійського державного агротехнологічного університету (економічні науки), № 4 (28), c. 64-72.

Прокопа, І. В. (2005). Соціальні аспекти розвитку сільських територій. Економіка АПК, № 11, с. 48-51.

Розміщення продуктивних сил. (1998). За В. В. Ковалевського, О. Л. Михайлик, В. Ф. Семенова. Киев: «Знання», $398 \mathrm{c}$.

Стратегічні напрями розвитку сільського господарства України на період до 2020 року. (2012). За ред. Ю. О. Лупенка, В. Я. Меселя-Веселяка [2-ге вид., переробл. і доповн.]. Киев: ННЦ «ІАЕ», 218 с.

Теорія, політика та практика сільського розвитку. (2010). За ред. О. М. Бородіної, І. В. Прокопи. Киев.

Соединенные Штаты Америки. (1960). Словарь-справочник. Под общ. ред. А. А. Арзуманяна, Н. В. Мостовец, М. А. Харламова. США-Москва: Госполитиздат, с. 611. Internet access: http://geography.su/books/item/f00/s00/ z000000 6/st109.shtml

28 Українська модель аграрного розвитку та ії соціоекономічна переорієнтація: наук (2012). За ред. В. М. Геєця, О. М. Бородіної, І. В. Прокопи. НАН України, Киев, 56 с.

Українське село: проблеми і перспективи (1991). За ред. Л.О. Шепотько. Киев: Урожай, 240 с.

Хольцер, 3. (2009). Пермакультура Зеппа Зольцера. Практическое применение для сада, огорода и сельского хозяйства, Ч. 1. Орел: С. В. Зенина, 160 с.

Юрчишин, В. (2011). Селяни України: про себе і про них. Киев: ННЦ IAE, 74 с. 


\section{KONCEPTUALUS UKRAINOS KAIMO PLÉTROS PAGRINDAS}

Maria Plotnikova

Žytomiro nacionalinis agroekologinis universitetas (Ukraina)

\section{Santrauka}

Egzistuojanti nedarna, siekiant darnaus kaimo vietovių vystymosi, paskatino pasirinkti būtent šią tyrimo temą. Šio straipsnio tikslas - surasti ir išanalizuoti sritis bei mechanizmus, kurių taikymas užtikrintų tvarkingą kaimo vietovių plètrą, auginant maistui tinkamus augalus, ekonominio saugumo, ekologinės žemdirbystès, gyvenimo be atliekų, taikant naujus metodus ir apmokant gyventojus juos taikyti. Tyrimas apima laikotarpi nuo 1991 iki 2014 metų. Rezultatai vertinti taikant sociometrinius ir statistinius metodus. Teorinis ir metodologinis mokslinio tyrimo pagrindas - sisteminis-sinerginis požiūris ir socialinių-ekonominių procesų modeliavimas. Straipsnyje atlikta teorinè analizè, aprašyta pateikiant ukrainiečių ir užsienio mokslininkų tyrimo rezultatus, kur analizuojami kaimo plètros, regioniniai ir nacionalinès ekonomikos klausimai, analizuoti ir vidaus bei tarptautinès teisès aktai. Tyrimo rezultatai remiasi jų pačių pastebejimų statistiniais rezultatais (modernių požiūrių ị valdymą ir kaimo vietovès analizė bei pritaikytas metodiškas požiūris, siekiant įvertinti jų veiksmingumą); sistemų analize ir sistemų teorija (apibrèžti kaimo plètros veiksniai ir sukurta daugiafunkcio požiūrio ị jo valdymą koncepcija); ekonometrine analize (išnagrinètos stabilumo sąlygos, ilgalaikès plètros mechanizmai). Šalies demografinių, maisto ir ekonominio saugumo tendencijų rezultatas atskleidè kryptingos, motyvuojančios žemès ūkio politikos trūkumą, valstybinès žemès ūkio plètros ir gyvenimo standartų Ukrainoje pasekmes.

PAGRINDINIAI ŽODŽIAI: investicijos, inovacijos, valdymas, plètra kaimo teritorijose.

JEL KLASIFIKACIJA: D 83, O 10, R 28, Q 01, Q 18 